\title{
Optimization of Drying Temperature in the Production Process of Tea Seed Oil
}

\author{
Sahrial Hafids, Emanauli, Rudi Prihantoro \\ Department of Agroindustrial Technology, Faculty of Agricultural Engineering and Technology, Jambi University, Jl. Tri Brata KM 11, \\ Pondok Meja, Mestong, Muaro Jambi 36364, Indonesia \\ E-mail:sahrial@unja.ac.id
}

\begin{abstract}
This study aims to determine the optimal temperature for drying kernel flour from tea seeds which will be used as raw material in the production of tea seed oil (TSO) by maceration method using n-hexane solvent. The study used a completely randomized design with 6 treatments for drying temperatures, namely: 60, 70, 80, 90, 100, and $110^{\circ} \mathrm{C}$. The results showed that the optimal temperature for drying kernel flour from tea seeds was $80^{\circ} \mathrm{C}$ with a drying time of 3.5 hours. At the optimum temperature obtained TSO yield of $16.12 \%$ with free fatty acid content of $0.40 \%$, iodine number $30.16 \mathrm{~g} \mathrm{I} / 100 \mathrm{~g}$ of material, peroxide number $0.16 \mathrm{meq} \mathrm{KOH}$ $/ 100 \mathrm{~g}$, saponification number $144.55 \mathrm{mg} \mathrm{KOH} / \mathrm{g}$ TSO, specific gravity $0.94 \mathrm{~g} / \mathrm{ml}$, refractive index 1.67 , and melting point $2.0^{\circ} \mathrm{C}$.
\end{abstract}

Keywords - optimization; drying temperature; production process; tea seed oil

\section{INTRODUCTION}

Tea is one of the plantation commodities which have an important role in the economy in Indonesia. This plant is included in the top seven leading plantation commodities in Indonesia [1]. So far, the tea plants have only been used as leaves for drinks. However, in addition to the leaves, all parts of the tea plant have the potential to be utilized, one of which is tea kernels [2] and [3].

Tea kernels contain $20-26 \%$ saponins, $20-60 \%$ oil, and $11 \%$ protein. Unripe kernels from tea seeds do not yet contain saponins and oil [4], so that in this study, the tea seeds used were old tea seeds with physical characteristics of dark greenish fruit skin color, brown shell, and yellowish white kernel color. Tea seed oil is obtained through maceration.

Maceration is an extraction method with the principle of equilibrium of concentration, by soaking the material in a solvent. The advantages of maceration method compared to other methods are work procedures and equipment used relatively simple, and can be used for materials that are resistant or not heat resistant [5].

The maceration method is based on the principle of solubility "like dissolve like" where polar solvents will dissolve polar compounds and non-polar solvents will dissolve non-polar compounds. In this study the solvent used was nhexane. The n-hexane solvent is a non-polar solvent that is often used for extraction processes. This is because n-hexane has high stability, volatility and low corrosion, and with little residue left behind [6].

The main requirements for the material before extraction using the maceration method are the opening of the cell wall pores of the material [6]. In this research, size reducing and drying of the kernel was carried out break down and open the pores of the material. The drying aims to reduce the moisture content of the kernel before extraction, so that it can increase the yield of extraction. According to [7] the optimum moisture content for the grains to be extracted is 6 to $7 \%$.
Drying also causes denaturized of protein so that oil becomes easier to exit when extracted. However, excessive drying can cause damage to the cell wall which can hinder the process of oil diffusion. In addition, over-drying can result in damage to the oil produced [4]. This study aims to determine the optimum drying temperature of tea kernel flour to be macerated using n-hexane solvent.

\section{MAterial AND METHODS}

\section{A. Material}

The materials used include raw materials and analytical materials. The raw material was old tea seeds and n-hexane solvents. Tea fruit was obtained from the Tea Plantation in Kayu Aro District, Kerinci Regency. The tea fruit samples used have the following characteristics: number of segments (1, 2 and 3 segments), seed diameter $(2.0-3.2 \mathrm{~cm})$, kernel diameter $(1.30-1.65 \mathrm{~cm})$, dark green skin color with black spots, brown shell, and yellowish white kernel color. The analysis material consisted of: ethanol, $0.1 \mathrm{~N} \mathrm{NaOH}, 1 \%$ phenolphthalein, chloroform, Wijs solution, $\mathrm{Na}_{2} \mathrm{~S}_{2} \mathrm{O}_{3} 0.1 \mathrm{~N}$, $0.5 \%$ starch solution, glacial acid, saturated $\mathrm{KI}, \mathrm{KOH} 0.5 \mathrm{~N}$, and $0.5 \mathrm{~N} \mathrm{HCl}$.

\section{B. Methods}

This study used a completely randomized design with six levels of treatment of kernel drying temperature, namely: 60, $70,80,90,100$, and $110^{\circ} \mathrm{C}$ with three replications.

The research was conducted in 2 stages of the process. First stage, the tea fruit was dried until it breaks, then peels until the dried tea seeds were obtained. Then, dried tea seed separated from the shell.

Size reducing of the kernel by sliced and blended. Size reducing was intended to allow the oil glands in the kernel to open as much as possible, so that the process of maceration more easily to get out oil of the material. 
Furthermore, $400 \mathrm{~g}$ of kernel flour was weighed and dried in an oven at the treatment temperature to reach a maximum moisture content of $10 \%$ (measurement of moisture content using the Moisture Analyzer). After reaching a maximum moisture content of $10 \%$, the oil content of the kernel flour was measured using the Soxhletation Method.

The second step, the dried kernel flour were weighed as much as $150 \mathrm{~g}$ for each treatment, then put in a $1,000 \mathrm{ml}$ erlenmeyer flask. Into the flask is added $450 \mathrm{ml} \mathrm{n}$-hexane (material/solvent ratio $1: 3 \mathrm{~b} / \mathrm{v}$ ), then macerated for $3 \times 24$ hours and stirred. After $3 \times 24$ hours, the maceration process is stopped. Next, filtering was carried out to separate the kernel flour pulp from TSO extraction and n-hexane solvent.

Separation of TSO from n-hexane solvents was carried out using Vacuum Rotary-Evaporator at the temperature of the boiling point of $n$-hexane $\left(60^{\circ} \mathrm{C}\right)$. The result of this separation is tea seed oil (TSO).

\section{RESUlT AND DisCUSSION}

\section{A. TSO Yield}

Drying aims to reduce the moisture content of kernel flour to a moisture content below $10 \%$ by using an oven at a temperature according to the treatment, namely: $60,70,80$, 90,100 , and $110^{\circ} \mathrm{C}$. Table 1 . presents the time needed to achieve kernel flour moisture content below $10 \%$ at each treatment temperature. Drying time of 2.5 to 4.0 hours were required to reduce the kernel moisture content to a moisture content below $10 \%$. The increase in drying temperature accelerates the process of decreasing moisture content. Figure 1. shows the closeness of the relationship of drying temperature to the moisture content of kernel flour with a value of $r^{2}=0.938$.

TABLE I

The EFFeCt Of TEMPERATURE AND Drying Time ON KERNEL MOISTURE CONTENT

\begin{tabular}{ccc}
\hline $\begin{array}{c}\text { Temperature } \\
\left({ }^{\mathbf{0}} \mathbf{C}\right)\end{array}$ & $\begin{array}{c}\text { Drying Time } \\
\text { (hours) }\end{array}$ & $\begin{array}{c}\text { Moisture } \\
\text { Content (\%) }\end{array}$ \\
\hline 60 & 4.0 & 9.91 \\
\hline 70 & 3.5 & 9.87 \\
\hline 80 & 3.5 & 8.44 \\
\hline 90 & 3.0 & 8.20 \\
\hline 100 & 2.5 & 7.83 \\
\hline 110 & 2.5 & 7.07 \\
\hline
\end{tabular}

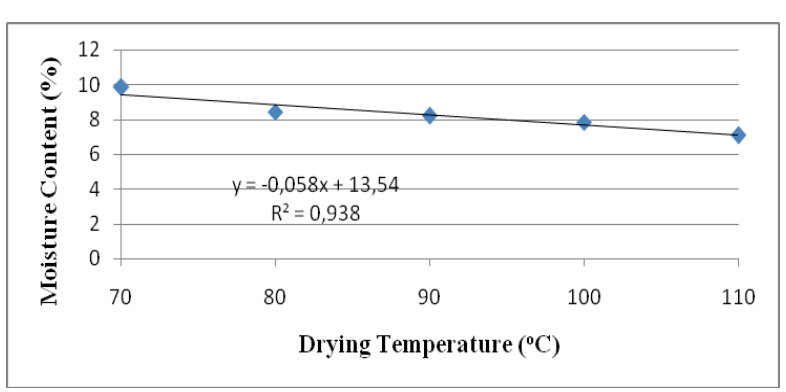

Fig. 1 The effect of drying temperature on kernel moisture content

According to [8], the best drying temperature for Jatropha kernel flour is $70^{\circ} \mathrm{C}$ for 4.83 hours. From this study it was known, that the highest TSO yield was produced from drying process of kernel flour at $110^{\circ} \mathrm{C}$ for 2.5 hours (Table 2).

TABLE II

The Effect of Moisture Content on Oil Content And TSO Yield

\begin{tabular}{ccc}
\hline $\begin{array}{c}\text { Moisture } \\
\text { Content (\%) }\end{array}$ & Oil Content (\%) & TSO Yield (\%) \\
\hline 7.07 & 19,67 & 19,02 \\
\hline 7.83 & 17,99 & 17,93 \\
\hline 8.20 & 17,07 & 16,22 \\
\hline 8.44 & 16,75 & 16,12 \\
\hline 9.87 & 16,06 & 15,92 \\
\hline 9.91 & 15,62 & 15,48 \\
\hline
\end{tabular}

Drying at $110^{\circ} \mathrm{C}$ for 2.5 hours reduced the moisture content of kernel flour to a moisture content of $7.07 \%$ which was the lowest moisture content compared to the other five treatments. The implication was produced by kernel flour with the highest oil content. Figure 2 shows the relationship of moisture content with oil content of kernel flour with a value of $\mathrm{r}^{2}=0.876$. While Figure 3 shows the relationship of oil content with the yield of TSO produced with a value of $r^{2}=$ 0.948 .

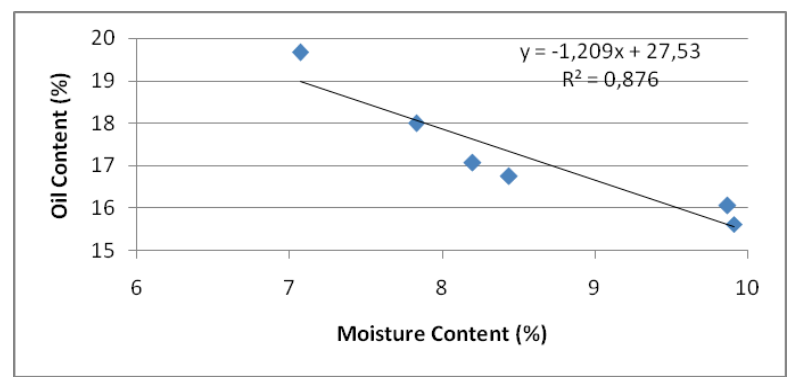

Fig. 2 The relationship of moisture content with oil content

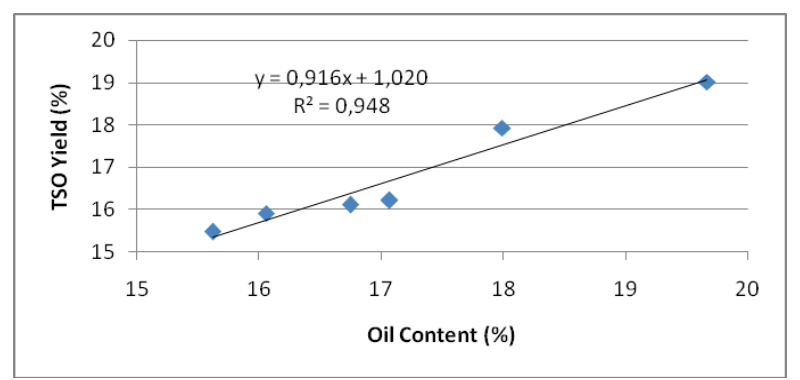

Fig. 3 The relationship of oil content with TSO Yield

From Figure 1 to 3 it was known, that there is a relationship between moisture content and oil content of the kernel which has implications for the yield of TSO. Increasing the drying temperature causes a decrease in moisture content (Figure 1.). Conversely, a decrease in moisture content will increase the oil content in the kernel flour (Figure 2.). The implication was that increasing the oil content in the kernel flour will increase the yield of the tea seed oil produced (Figure 3.). Thus, it can be concluded, that an increase in the drying temperature can increase the yield of the TSO produced. However, an increase in drying temperature can 
result in damage to the oil produced [4], so that the optimum temperature for the drying process of kernel flour is needed.

\section{B. Optimization of Drying Temperature}

From the results of the analysis of physicochemical properties of tea seed oil (TSO) produced, it was found that the drying process only affected the content of free fatty acids (FFA). Thus, determining the optimum drying temperature was based on FFA parameters using the lowest FFA value criteria. With these criteria, it was known, that the optimum temperature for drying kernel flour to be used as raw material for TSO production process using maceration method and nhexane solvent is at a temperature of $80^{\circ} \mathrm{C}$ with a drying time of 3.5 hours (Table 3 ).

TABLE III

The EFFect of Temperature AND Drying Time on FFA CONTENT

\begin{tabular}{ccc}
\hline $\begin{array}{c}\text { Temperature } \\
\left({ }^{\mathbf{0}} \mathbf{C}\right)\end{array}$ & $\begin{array}{c}\text { Drying Time } \\
\text { (hours) }\end{array}$ & FFA (\%) \\
\hline 60 & 4.0 & $0.92 \mathrm{a}$ \\
\hline 70 & 3.5 & $0.84 \mathrm{a}$ \\
\hline 80 & 3.5 & $0.40 \mathrm{~b}$ \\
\hline 90 & 3.0 & $0.85 \mathrm{a}$ \\
\hline 100 & 2.5 & $0.56 \quad \mathrm{c}$ \\
\hline 110 & 2.5 & $0.64 \quad \mathrm{c}$ \\
\hline
\end{tabular}

FFA is an important parameter in determining oil quality. The high FFA content in oil can cause damage to oil, so the oil does not last long to store. The content of FFA in oil is the result of the hydrolysis of triglycerides. In the hydrolysis reaction FFA and glycerol molecules are produced. This hydrolysis process can take place when oil is still in the seed tissue, when harvested, handling, processing, or during storage [9].

\section{Physicochemical Properties of TSO}

The physical properties of tea seed oil (TSO) produced from this study can be seen in Table 4. The chemical properties can be seen in Table 5 .

TABLE IV

The Physical Properties of TSO

\begin{tabular}{lcc}
\hline \multicolumn{1}{c}{ Physical Properties } & Unit & Value \\
\hline Specific Gravity & g.ml ${ }^{-1}$ & 0.94 \\
\hline Refractive Index & non dimension & 1.67 \\
\hline Melting Point & ${ }^{\circ} \mathrm{C}$ & 2.0 \\
\hline
\end{tabular}

TABLE V

The Chemical Properties of TSO

\begin{tabular}{lcc}
\hline \multicolumn{1}{c}{ Chemical Properties } & Unit & Value \\
\hline Iodine Number & $\mathrm{g} \mathrm{I}_{2} / 100 \mathrm{~g}$ & 30.16 \\
\hline Peroxide Number & $\mathrm{meq} \mathrm{KOH} / 100 \mathrm{~g}$ & 0.16 \\
\hline Saponification Number & $\mathrm{mg} \mathrm{KOH} / \mathrm{g}$ & 144.55 \\
\hline
\end{tabular}

\section{Specific Gravity}

Specific gravity is one of the parameters of quality and purity of oil content. Specific gravity states the ratio of the weight of a volume of material to the weight of water with the same volume at a temperature of $25^{\circ} \mathrm{C}$ [10] and [11]. Density relates to the weight of the fractions of components carried in oil. The increase in the weight fraction contained in oil will cause an increase in the value of the specific gravity of the oil. In general, oils that contain long-chain molecules or with multiple double bonds have a high density [11].

\section{$\underline{\text { Refractive Index }}$}

The refractive index is used to show the purity and quality of the oil. Refractive index is a comparison between the speed of light in the air and inside the substance [10]. According to [12] oil that has good quality is oil that has a high refractive index.

The size of the refractive index is related to the fatty acid components. Fatty acid molecules with high unsaturated bonds or many oxygen groups have a greater refractive index [10], [11], and [13].

\section{Melting Point}

The melting point is the temperature at the time of the first droplet occurring from the oil until it finishes melting [11]. Melting point is influenced by the degree of unsaturation of fatty acids. Oils that have a high degree of unsaturation have a low melting point. In unsaturated fatty acids, the nature of the melting point is influenced by the number of double bonds, configuration, and position of double bonds.

\section{Iodine Number}

Iodine number states the amount of iodine absorbed by oil. The amount of iodine absorbed shows the number of unsaturated bonds [14]. The degree of oil unsaturation is determined by the components of unsaturated fatty acids, especially oleic acid and linoleic acid. Fatty acids that are not saturated in TSO can absorb iodine and form saturated compounds. According to [15] oil with a low iodine number has a low melting point. Melting points indicate the lowest temperature at which oil can melt from the solid phase.

\section{Peroxide Number}

Peroxide number is one of the most important values for determining the degree of damage to oil. The maximum limit of peroxide content in oil is 10 meq $\mathrm{O}_{2} / 100 \mathrm{~g}$ of oil [16]. Oils with peroxide numbers that exceed the maximum limit can poison the body, especially in foods containing peroxide numbers of more than 10 meq $\mathrm{O}_{2} / 100 \mathrm{~g}$ [17].

Peroxide numbers can be used to find out whether the oil has been oxidized or not [18]. Oil oxidation occurs spontaneously with the speed of the oxidation process depending on the type of oil and storage conditions [11]. Good oil has a low peroxide level, so the lower the peroxide number the better the quality of the oil [17].

\section{Saponification Number}

The saponification number indicates the amount of $\mathrm{mg}$ of potassium hydroxide $(\mathrm{KOH})$ needed to saponification 1 gram of oil [16]. The saponification number measures the molecular weight or chain length of the fatty acid in an oil sample. High saponification numbers indicate fatty acid making up triglycerides having a short carbon chain [11]. 


\section{CONCLUSION}

The optimum temperature for kernel flour drying for production process of tea seed oil is $80^{\circ} \mathrm{C}$ with a drying time of 3.5 hours. At the optimum temperature obtained TSO yield of $16.12 \%$ with free fatty acid content of $0.40 \%$, Iodine number $30.16 \mathrm{~g} \mathrm{I}_{2} / 100 \mathrm{~g}$ of material, Peroxide number 0.16 meq $\mathrm{KOH} / 100 \mathrm{~g}$, saponification number $144.55 \mathrm{mg} \mathrm{KOH} / \mathrm{g}$ TSO, specific gravity $0.94 \mathrm{~g} / \mathrm{ml}$, refractive index 1.67 , and melting point $2.0^{\circ} \mathrm{C}$.

\section{REFERENCES}

[1] [CBS] Central Bureau of Statistics. 2017. Indonesian Plantation Statistics. Central Bureau of Statistics, Jakarta.

[2] Setyamidjaja, D. 2000. Cultivation and Processing of Post-Harvest of Tea. Kanisius, Yogyakarta.

[3] Sahrial, Emanauli, and M. Arisandi. 2017. Physicochemical Properties of Tea Seed Oil and Its Potential Applications. Agroindustry Journal, Vol. 7 (2): 111-115.

[4] Susiana, P. S., A. Prima, and Y. Felicia. 2011. Effect of the Ratio of Tea Seed/Water Solvents and Temperature to Batch Tea Saponin Extraction. Parahyangan Catholic University, Bandung.

[5] Fitrah, D., M.S. Sandra, and Y. Rini. 2014. Effect of extraction time and ethanol concentration on the antioxidant extraction of cocoa beans (Theobroma cacao 1.). Brawijaya University, Malang.

[6] Orhevba, A. B and O.A. Jinadu. 2011. Determination of Physicochemical Properties and Nutritional Contents of Avocado Pear (Persea americana M.). University of Technology, Niger State.

[7] Frans, D.S.G. 2010. Effect of drying on the yield of castor oil (Jatropha Curcas 1.). IPB, Bogor.
[8] Verra, M., A. Usman, and W. Sri. 2012. Study of Handling Materials and Drying Methods on Seed Quality and Jatropha Oil (Jatropha curcas L.), Agricultural Engineering, Faculty of Agricultural Technology. IPB, Bogor.

[9] Mulyati, H. 2000. Study of the drying parameters of encrypted castor fruit (Ricinus communis L). Faculty of Agricultural Technology. IPB, Bogor.

[10] Guenther, E., 1987. Essential Oils. Volume I. University of Indonesia, Jakarta.

[11] Ketaren, S. 2008. Introduction to Technology of Oil and Fat. UI-Press, Jakarta.

[12] Sutiah, K., S. Firdausi, and W.S. Budi. 2008. Study of Edible Oil Quality with Viscosity and Bias Index. Periodic Physics. Vol. 11(2).

[13] Vinny, Ch., O. Koong., Meiske, S. Sangi., and J. Pontoh, 2013. Test of the Quality of Fennel Seed Oil (Foeniculum vulgare) obtained by the Soxhletation Method. Sam Ratulangi University, Manado.

[14] Ariestya, A., K. Steviana, , and Ign. Suharto. 2010. Effect of temperature and $\mathrm{f} / \mathrm{s}$ on oil extraction from pecan seeds remaining mechanical emphasis. Parahyangan Catholic University, Bandung.

[15] Nugrahani, R.A. 2008. Designing a basic lubricant manufacturing process synthesized from Jatropha curcas L. through chemical modification. Dissertation. Postgraduate Program. IPB, Bogor.

[16] [NSA] National Standardization Agency. 2013. Cooking Oil Quality Standards. National Standardization Agency, Jakarta.

[17] Gunawan, T.M.A. Mudji, and R. Arianti. 2003. Analysis of Food: Determination of Numbers of Peroxides and Free Fatty Acids in Soybean Oil with Frying Variations, Diponegoro University, Semarang.

[18] Raharjo, S., 2006. Oxidative Damage of Food. Gadjah Mada University Press, Yogyakarta. 